MOTIVASI NARAPIDANA PEREMPUAN LAPAS

PEREMPUAN KELAS IIA BANDUNG DALAM MENGIKUTI PROGRAM PEMBINAAN KEMANDIRIAN

\section{Sri Sulistijaningsih}

Politeknik Ilmu Pemasyarakatan
Journal of Correctional Issues 2020, Vol.3 (2), 55-64

Politeknik Ilmu Pemasyarakatan

Review

20 Oktober 2020

Accepted

10 September 2020

\begin{abstract}
Prisoners in undergoing the crime of missing independence at the Penitentiary must be introduced to the community. Banyan Tree Protection Point.6). Prisoners must be given work and must be one with the community and support efforts to increase production. Bandung Women's Class IIA Penitentiary Institution is one of the Technical Implementation units of the Directorate General of Correctional Facility under the ranks of the West Java Province Ministry of Law and Human Rights office as a place to foster female prisoners in the field of independence fostering programs. Fostering the independence program is a form of fostering aimed at empowering female prisoners. It is hoped that they will be effective and efficient in empowering the family's economy, so that they can help a source of income for the family after being free from criminal punishment. The purpose of this study is to determine the motivation of women prisoners in Class IIA Bandung Women's Penitentiary in participating in a program to develop independence, find out the constraints of obstacles and provide solutions to overcome obstacles in the process of fostering Independence.
\end{abstract}

\title{
Keywords:
}

Motivation, Female prisoners, fostering Independence.

\begin{abstract}
Abstrak
Narapidana dalam menjalani pidana hilang kemerdekaan di Lembaga Pemasyarakatan harus dikenalkan dengan masyarakat. Pohon Beringin Pengayoman Point.6). Narapidana wajib diberikan pekerjaan dan harus satu dengan masyarakat serta menunjang usaha peningkatan produksi. Lembaga Pemasyarakataan Perempuan Kelas IIA Bandung adalah salah satu unit pelaksana Teknis Direktorat Jenderal Pemasyarakatan dibawah jajaran kantor wilayah kementerian hukum dan HAM Propinsi Jawa Barat merupakan tempat membina narapidana perempuan dibidang program pembinaan kemandirian. Pembinaan Program kemandirian merupakan salah satu bentuk pembinaan yang bertujuan untuk memberdayakan narapidana perempuan. Di harapkan mereka berhasil guna dan berdaya guna dalam pemberdayaan ekonomi keluarga, sehingga dapat membantu sumber pendapatan bagi keluarga setelah bebas menjalani Pidana. Tujuan dari penelitian ini adalah untuk mengetahui motivasi narapidana perempuan di Lembaga pemasyarakatan perempuan Kelas IIA Bandung dalam mengikuti program pembinaan kemandirian, mengetahui kendala kendala dan memberikan solusi untuk mengatasi kendala dalam proses pembinaan Kemandirian.
\end{abstract}

Katakunci:

Motivasi, Narapidana Perempuan, Program Kemandirian 


\section{Pendahuluan}

Tujuan sistem Pemasyarakatan adalah mengembalikan hubungan kesatuan hidup, kehidupan dan penghidupan. Dalam undang undang Pemasyarakatan pasal 2 menyebutkan "Sistem pemasyarakatan diselenggarakan dalam rangka membentuk warga binaan agar menjadi manusia seutuhnya, menyadari kesalahan, memperbaiki diri dan tidak mengulangi tindak pidana sehingga dapat diterima kembali oleh lingkungan masyarakat, dapat aktif berperan dalam pembangunan dan dapat hidup secara wajar sebagai warga negara yang baik dan bertanggungjawab."

Disamping bertujuan untuk mengembalikan warga binaan pemasyarakatan sebagai warga yang baik juga bertujuan untuk melindungi masyarakat terhadap kemungkinan diulanginya tindak pidana oleh mantan narapidana. Sistem pemasyarakatan bukan saja menjadikan narapidana sebagai obyek melainkan juga sebagai subyek karena yang diberantas adalah faktor-faktor yang dapat dikenakan pidana. Sistem pemasyarakatan sebagai upaya untuk menyadarkan warga binaan pemasyarakatan agar menyadari kesalahan, memperbaiki diri dan tidak mengulangi tindak pidana sehingga dapat diterima kembali oleh lingkungaan masyarakat dapat aktif berperan dalam pembangunan dan menjadi warga masyarakat yang baik taat pada hukum, menjunjung tinggi nilai nilai moral, sosial dan keagamaan sehingga tercapai kehidupan masyarakat yang aman, tertib dan damai. Proses pemasyarakatan mempunyai dua persektif (dua wajah) yaitu proses yang berlangsung dalam lingkungan bangunan (proses institusional) dan proses yang berlangsung secara penuh ditengah - tengah masyarakat (proses noninstitusional).

Narapidana sebagai warga negara Indonesia yang hilang kemerdekaan bergeraknya dibatasi oleh tembok penjara tetap diberlakukan sebagai warga negara walaupun dia telah melanggar hukum karena di dalam peraturan perundang-undangan warga negara yang melakukan tindak pidana tidak lantas menghilangkan haknya sebagai warga negara. Terkait dengan hal tersebut selama narapidana menjalani pidana di lembaga pemasyarakatan memiliki hak yang telah diatur dalam pasal 14 Undang - Undang Nomor.12 tahun 1995 tentang Pemasyarakatan, sebagai berikut :

a. Melakukan ibadah sesuai dengan agama atau kepercayaannya;

b. Mendapat perawatan, baik perawatan rohani maupun jasmani;

c. Mendapatkan pendidikan dan pengajaran;

d. Mendapatkan pelayanan kesehatan dan makanan yang layak;

e. Menyampaikan keluhan;

f. Mendapatkan bahan bacaan dan mengikuti siaran media massa lainnya yang tidak dilarang;

g. Mendapatkan upah atau premi atas pekerjaan yang dilakukannya;

h. Menerima kunjungan keluarga, penasehat hukum, atau orang tertentu lainnya;

i. Mendapatkan pengurangan masa pidana (remisi);

j. Mendapatkan kesempatan berasimilasi termasuk cuti mengunjungi keluarga;

k. Mendapatkan pembebasan bersyarat;

I. Mendapatkan cuti menjelang bebas; dan 
m. Mendapatkan hak-hak lain sesuai dengan peraturan perundangundangan.

Lapas perempuan kelas IIA Bandung adalah Unit Pelaksana teknis dibawah jajaran Kantor Wilayah kementerian Hukum dan Hak Asasi manusia propinsi Jawa Barat. Lapas khusus perempuan ini mempunyai tugas dan fungsi melakukan pembinaan dan perawatan khusus bagi warga binaan pemasyarakatan perempuan berada di bawah jajaran .

Di dalam pasal 2 ayat (1) Peraturan Pemerintah Republik Indonesia Nomor 31 Tahun 1999 Tentang Pembinaan Dan Pembimbingan Warga Binaan

Pemasyarakatan ayat (1) disebutkan : "Program pembinaan dan pembimbingan meliputi kegiatan pembinaan dan pembimbing kepribadian dan kemandirian". Dalam pasal 3 disebutkan pembinaan dan pembimbingan

kepribadian dan kemandirian meliputi hal-hal yang berkaitan dengan point : (h) keterampilan kerja; dan (i) latihan kerja dan produksi. Program pembinaan kemandirian di lapas juga telah diatur dalam sepuluh prinsip pemasyarakatan yaitu dalam angka (1) "Ayomi dan berikan bekal hidup agar mereka dapat menjalankan peranannya sebagai warga

masyarakat yang baik dan berguna". Pada angka (6) "Pekerjaan yang diberikan kepada narapidana dan anak didik tidak boleh diberikan pekerjaan untuk memenuhi kebutuhan dinas atau kepentingan negara sewaktu-waktu saja.

Pekerjaan yang diberikan harus satu dengan pekerjaan di masyarakat dan menunjang usaha peningkatan produksi".

Salah satu keberhasilan pembinaan dibidang kemandirian adalah adanya motivasi yang tinggi dari narapidana sebagai peserta pembinaan kemandirian dan staf serta pejabat bidang pembinaan yang bertindak sebagai intstruktur. Motivasi Menurut Malthis (2006:114), adalah keinginan dalam diri seseorang yang menyebabkan orang tersebut bertindak. Biasanya orang bertindak karena suatu alasan untuk mencapai tujuan. Memahami motivasi sangatlah penting karena kinerja, reaksi terhadap kompensasi dan persoalan sumber daya manusia yang lain dipengaruhi dan mempengaruhi motivasi. Pendekatan untuk memahami motivasi berbedabeda, karena teori yang berbeda mengembangkan pandangan dan model mereka sendiri. Motivasi menurut Vroom (dalam Kreitner \& Kinicki 2007 : 247), motivasi adalah mengarahkan dalam memutuskan seberapa besar upaya untuk mengerahkan usaha dalam situasi tertentu. Keitner \& Kinicki (2007) mendifinisikan motivasi sebagai proses psikologis yang menyebabkan munculnya suatu tindakan yang memiliki arah untuk mencapai tujuan tertentu. Morgan (1986 : 303) motivasi diartikan sebagai " untuk mendorong dan menekan dengan kuat yang akan muncul dalam perilaku yang gigih dalam mengarah pada pencapaian tujuan-tujuan tertentu". Robins (1998 : 50) Motivasi adalah "kesediaan untuk mengeluarkan tingkat upaya yang tinggi untuk tujuan organisasi, yang dikondisikan oleh kemampuan upaya itu dalam memenuhi beberapa kebutuhan individu".

Diharapkan motivasi narapidana dalam mengikuti program pembinaan kemandirian selama menjalani pidana didalam Lapas perempuan kelas IIA Bandung, dapat menjadi modal dasar dalam berwirausaha dan menciptakan lapangan pekerjaan sendiri setelah bebas menjalani hukuman. 


\section{Metode}

Metode yang digunakan dalam penelitian ini adalah metode penelitian deskriptif kualitatif karena peneliti ingin menggambarkan atau melukiskan faktafakta atau keadaan ataupun gejala yang tampak dalam Motivasi narapidana dalam mengikuti program pembinaan kemandirian. Penelitian deskriptif kualitatif adalah penelitian yang menggambarkan atau melukiskan objek penelitian berdasarkan fakta-fakta yang tampak atau sebagaimana adanya. Nawawi dan Martini (1996: 73). Penelitian deskriptif kualitatif berusaha mendeskripsikan seluruh gejala atau keadaan yang ada, yaitu keadaan gejala menurut apa adanya pada saat penelitian dilakukan. Mukhtar (2013: 28). Penulis menjadikan metode langsung dan metode tidak langsung,

Dengan menggunakan teknik analisis data kualitatif dalam pengambilan data, yaitu :

1. Hasil pengamatan dan wawancara kepada narapidana yang mengikuti program pembinaan kemandirian di lapas Kelas IIA Perempuan Bandung.

2. Hasil wawancara dan informasi dari staf dan pejabat yang berwenang dalam program Kemandirian di Lapas Perempuan kelas IIA Bandung.

3. Bahasan tertulis berita dimass media ,majalah, data base narapidana yang terkait dengan program pembinaan kemandirian di lapas perempuan kelas IIA Bandung.

4. Dalam penelitian ini penulis akan membahas tentang apa saja yang menjadi motivasi narapidana serta kendala kendala apa saja yang dihadapi dalam pelaksanaan program pembinaan kemandirian di lapas perempuan kelas IIA Bandung.

Motivasi adalah proses dimana kebutuhan kebutuhan mendorong seseorang untuk melakukan serangkaian kegiatan yang mengarah ketercapaiannya tujuan tertentu. Individu yang berhasil mencapai tujuan-nya tersebut berarti kebutuhan - kebutuhannya dapat terpenuhi atau terpuaskan (Munandar,2001). Motivasi adalah alat penggerak yang ada dalam setiap individu untuk mencapai suatu tujuan yang akan dicapai. Usaha yang diberikan dalam memotivasi seseorang dilakukan dengan cara memunculkan faktor-faktor yang mendorong individu berperilaku tertentu. Hal tersebut dapat dilakukan dengan jalan memberikan imbalan, menciptakan persaingan, melatih, menasehati dan lainnya (Hariandja, 2002).

Sadili Samsudin (2006) menyatakan bahwa motivasi kerja merupakan sesuatu yang menimbulkan dorongan atau semangat kerja. David McCelland (1998) menyatakan bahwa motivasi seseorang itu cenderung memiliki pola motivasi yang terdiri atas : a. Motivasi berprestasi (Achievement Motivation) b. Motivasi afiliasi (Afilliation Motivation) c. Motivasi kompetensi (Competence Motivation) d. Motivasi kekuasaan (Power Motivation)

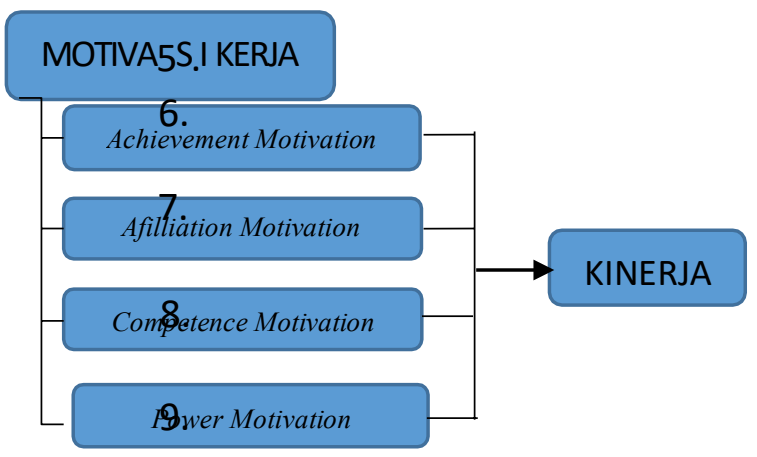

Gambar 1 :

Kerangka Pemikiran 
Hipotesis dalam Penelitian ini Berdasarkan uraian pada latar belakang masalah, identifikasi dan perumusan masalah yang didukung dengan kajian teoritis yang dilengkapi juga dengan kerangka pemikiran sehingga dapat dikemukakan bahwa hipotesis penelitian terdapat pengaruh positif dari motivasi kerja Narapidana perempuan pada Lapas perempuan kelas IIA Bandung. Metode Penelitian bersifat diskriptis analisis kualitatif . Obyek penelitian Populasi dan Sampel Populasi dalam penelitian merupakan sumber data, artinya sifat atau karateristik dari sekelompok subjek. Sesuai dengan pendapat Sugiyono (2002:57) yang mengemukakan bahwa, "Populasi adalah wilayah generalisasi yang terdiri atas objek atau subjek yang mempunyai kuantitas dan karateristik tertentu yang ditetapkan oleh peneliti untuk dipelajari dan kemudian ditarik kesimpulan". Adapun yang menjadi populasi dalam penelitian ini adalah Narapidana di lapas perempuan kelas IIA Bandung yang mengikuti program pembinaan kemandirian sebanyak 49 orang. Penulis melakukan wawancara kepada peserta program pembinaan kemandirian sebanyak duapuluh narapidana secara acak, tiga orang petugas yang terdiri dari satu orang pejabat yaitu kasubsi kegiatan kerja dan dua orang staf bimbingan kerja.

\section{Hasil}

Kondisi lapas perempuan kelas IIA Bandung mempunyai kapasitas 325 orang, penelitian dilakukan hari sabtu tanggal. 18 januari 2020 dengan jumlah penghuni sebanyak 438 orang. Dari jumlah total narapidana 438 orang, terdapat narapidana dengan kasus narkoba 279 orang; narapidana kasus korupsi 38 orang; narapidana kasus umum 100 orang; narapidana kasus terorisme 2 orang; narapidana kasus trafficking 14 orang; narapidana kasus money loundring 5 orang. Narapidana yang menjalani program pembinaan lanjutan berupa cuti bersyarat ( CB) 17 orang.
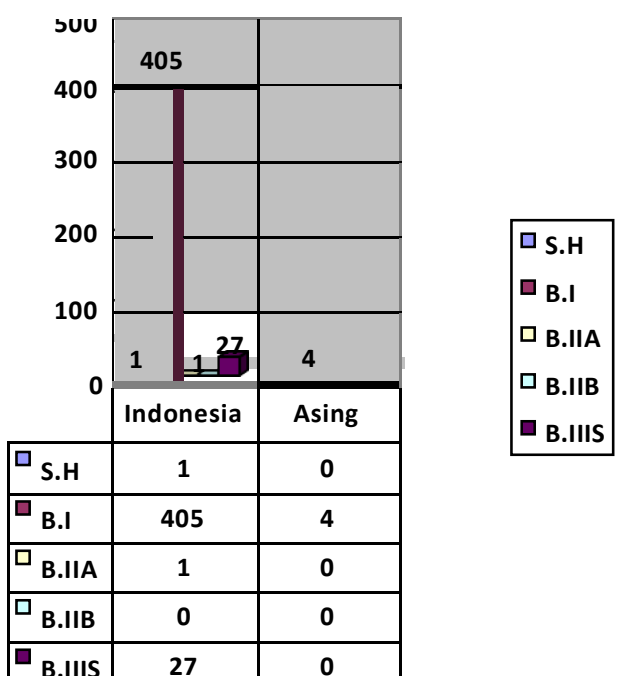

Gambar 2 : Jumlah narapidana

Struktur organisasi dan tata kerja lembaga pemasyarakatan perempuan kelas IIA Bandung berdasarkan Keputusan Menteri Kehakiman dan Hak Asasi Manusia RI No : M. 01- PR-07-10 tahun 2001 tentang Organisasi dan Tata Kerja Departemen Kehakiman dan Hak Asasi Manusia RI. Dalam melaksanakan Program Kerja didukung oleh jajaran SDM dengan jumlah pegawai serta tingkat pendidikan yang relatif memadai. Lembaga pemasyarakatan perempuan Kelas IIA Bandung memiliki pegawai berjumlah : 94 orang, terdiri dari pegawai laki-laki : 33 orang, pegawai perempuan : 61 orang. Latar belakang pendidikan terakhir S2 : 2 orang ; pendidkan terakhir S1 : 35 orang; pendidikan terakhir D3 : 5 orang; dan pendidikan terakhir Sekolah lanjutan Tingkat Atas (SLTA) berjumlah 52 orang, gambar 2 menggambarkan kondisi 
pendidikan terakhir pegawai lapas perempuan kelas IIA Bandung.

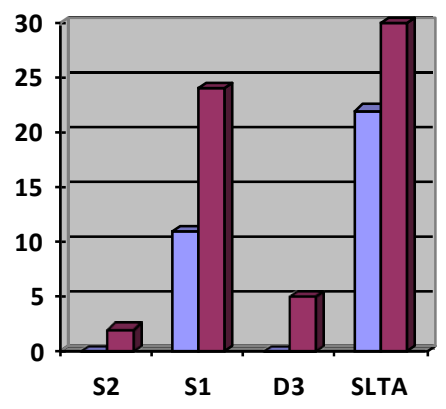

Gambar 2: Jumlah Pegawai

Program pembinaan kemandirian di lapas kelas IIA Bandung diikuti oleh 54 orang narapidana (12\%) dari seluruh narapidana ( 445 ) orang. Program pembinaan kemandirian terbanyak pesertanya adalah pos kegiatan pertamanan sebanyak 12 orang (22 \%) dari seluruh peserta kegiatan program pembinaan kemandirian. Kegiatan Pembinaan Kemandirian yang paling sedikit diikuti adalah program kerja salon diikuti 3 orang narapidana ( $6 \%$ ). Kegiatan Program kemandirian dibagi dalam delapan pos kegiatan antara lain :

1. Taman ; 2.. salon 3. Melukis; 4.Assesories / perca; Perkebunan ; 6.Tataboga; 7.Menyulam; 8.Menjahit.

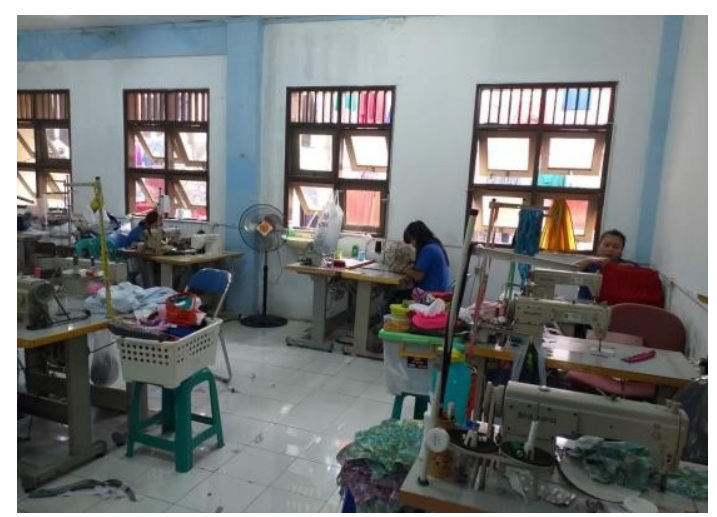

Gambar 3: Menjahit

\section{Pembahasan}

1. Jenis Kegiatan program kemandirian
Pembinaan kemandirian diikuti 54 (lima puluh empat ) orang narapidana seluruh narapidana yang berjumlah 445 orang. Kegiatan Program kemandirian terdiri dalam delapan pos kegiatan antara lain : 1. Taman ; 2. Salon 3. Melukis; 4. Assesories / perca; Perkebunan ; 6.Tataboga;7.Menyulam; 8.Menjahit. Jenis kegiatan dan jumlah peserta program pembinaan kemandirian dapat dilihat pada gambar 4 dibawah ini.

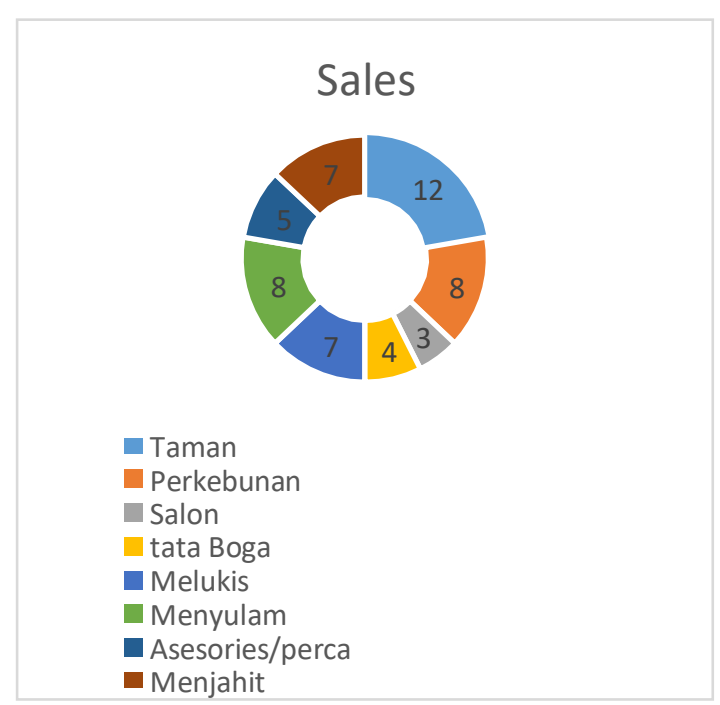

Gambar4: peserta program Kemandirian

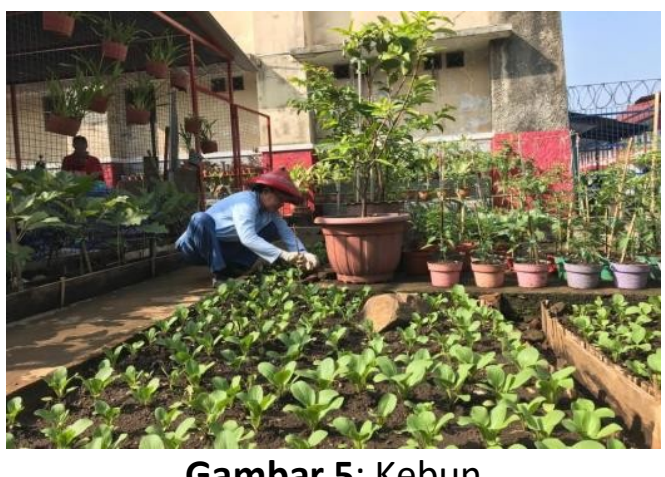

Dalam pelaksanaan program pembinaan kemandirian supaya dapat berjalan lancar dan effisien karena terbatasnya sumber daya petugas baik secara kualitas maupun secara kuantitas, maka dalam pelaksanaan program kemandirian di lapas perempuan kelas IIA 
Bandung dibantu oleh narapidana yang diangkat sebagai pemuka kerja dan dua orang tamping, tamping jahit dan tamping kebun. Pemuka kerja dan tamping dipilih dari narapidana yang telah memenuhi persyaratan dan ditetapkan dalam sidang Tim Pengamat Pemasyarakatan (TPP), dihadiri oleh seluruh anggota TPP terdiri dari Kepala Seksi Pembinaan dan Anak Didik (Binadik); Kepala Kesatuan Pengamanan Lapas (KPLP); Kepala Sub.seksi Bimbingan dan Perawatan dan anak didik, kepala Seksi Kemanan dan Ketertiban; Kepala seksi Kegiatan kerja; Kepala Sub seksi Sarana Kerja; kepala subseksi Registrasi, Pembimbing Kemasyarakatan (PK); Para wali Narapidana, dan keluarga narapidana.

Peraturan yang mengatur tentang pengangkatan dan pemberhentian tamping dan pemuka, diatur dalam Peraturan Menteri Hukum Dan Hak Asasi Manusia Republik Indonesia Nomor 9 Tahun 2019 Tentang Perubahan Atas Peraturan Menteri Hukum Dan Hak Asasi Manusia Nomor 7 Tahun 2013 Tentang Pengangkatan Dan Pemberhentian Pemuka Dan Tamping Pada Lembaga Pemasyarakatan diatur tentang syarat diangkat menjadi pemuka diatur dalam Pasal 5 (1) Untuk diangkat menjadi Pemuka, Narapidana harus memenuhi syarat sebagai berikut: a. masa pidana paling sedikit 3 (tiga) tahun; $b$. telah menjalani $1 / 3$ (satu per tiga) masa pidana; c. tidak pernah melanggar tata tertib dan tercatat dalam register $\mathrm{F}$; $\mathrm{d}$. sehat jasmani dan rohani; e. pernah diangkat sebagai Tamping paling sedikit 6 (enam) bulan; f. mempunyai kecakapan dan keterampilan khusus; g. mempunyai bakat memimpin; dan h. mempunyai jiwa sosial. Tugas pemuka membantu kegiatan dibidang : a. kegiatan kerja; $b$. pendidikan; c. keagamaan; d. olahraga; e. kesenian; f. kebersihan lingkungan; dan g. kegiatan industry, diatur dalam Pasal 6 .

\section{Latar Belakang Keterampilan Peserta} Narapidana peserta program pembinaan kemandirian berlatar memiliki :

a. Latar belakang keterampilan yang di bawa dari luar lapas, sebelum mereka menjalani masa hukuman di lapas narapidana telah memiliki kemampuan dan keterampilan di pos kerja masing - masing. Narapidana yang memiliki keterampilan dari luar terdapat pada pos kerja : salon; menjahit tataboga.

b. Narapidana Tidak memiliki keterampilan sama sekali di bidang pos kerjanya. Narapidana pada kriteria ini baru memiliki ketrampilan setelah mengikuti program pelatihan di lapas. Narapidna dalam kriteria ini terdapat pada pos kerja : taman; perkebunan; lukis ; merajut dan assesories/perca.

\section{Premi / Upah kerja}

Peraturan mengenai Pendapatan Negara Bukan Pajak (PNBP) di lingkungan Kementerian Hukum dan Hak Asasi Manusia diatur berdasarkan Peraturan Pemerintah Nomor.45 Tahun 2014 tentang jenis dan tarif atas jenis penerimaan negara bukan pajak yang berlaku pada Kementerian Hukum dan Hak Asasi Manusia dalam peraturan pemerintah dijelaskan pada pasal 1 ayat 1 point G : "Jenis Penerimaan Negara Bukan Pajak yang berlaku pada Kementerian Hukum dan Hak Asasi manusia meliputi penerimaan dari : Kegiatan kerja sama dengan pihak lain dalam rangka pembinaan kemandirian warga binaan pemasyarakatan". Program 
Kegiatan Kemandirian Lapas perempuan Kelas IIA Bandung tidak mempunyai kewajiban untuk menyetorkan PNBP atas program pembinaan bidang kemandirian, karena program kegiatan kemandirian di lapas perempuan kelas IIA Bandung belum melakukan kerjasama dengan pihak ketiga. Pembagian upah hasil kerja program kemandirian di Lapas perempuan kelas IIA Bandung diatur berdasarkan ketentuan internal Lapas tentang pembagian upah dalam kegiatan kerja. Upah yang diberikan bagi peserta program pembinaan kemandirian tidak sama besarannya bagi narapidana, besarnya upah diberikan berdasarkan kriteria : 1.Bidang pekerjaan yang dilakukan; 2.Tingkat kesulitan bidang pekerjaan yang dikerjakan ; 3 . Banyaknya konsumen yang memakai jasa (berdasarkan pesanan); 4.Banyaknya Jumlah pekerjaan yang dikerjakan.

\section{Tujuan Mengikuti Kegiatan}

a. Narapidana termotivasi mengikuti program pembinaan kemandirian supaya tidak menganggur. Tidak mempunyai kegiatan hanya ngobrol sana ngobrol sini membuat waktu terasa lama dalam menjalani hukuman di Lapas.

b. Untuk menambah pengalaman di bidang keterampilan selama menjalai hukuman di lapas.

c. Untuk mendapatkan upah, untuk membeli kebutuhan sehari hari yang tidak disediakan oleh Lapas. Kebutuhan tersebut antara lain sabun mandi,sabun cuci, shampo, pembalut, lipstick. Selain itu juga upah disisihkan untuk dikirimkan ke adeknya sebagai biaya sekolah dipondok pesantren.

d. Untuk mendapatkan keterampilan dari Lapas sehingga dapat dikembangkan dan dijadikan

$\begin{array}{llr}\text { sumber pendapatan } & \text { keluarga, } \\ \text { dengan berwirausaha } & \text { sesuai } \\ \text { dengan keterampilan } & \text { yang } \\ \text { diperolehnya selama menjalani } \\ \text { masa pidana di lapas. }\end{array}$

Dari keempat motivasi narapidana dalam mengikuti kegiatan program pembinaan kemandirian di Lapas, dan seiring dengan berjalannya waktu semula sekedar mengisi waktu, motivasi tersebut berkembang menjadi suatu keinginan untuk menjadikan keterampilan yang dimiliki sebagai bekal setelah bebas dan dapat dikembangkan sebagai sumber penghasilan untuk menopang ekonomi keluarga.Dapat disimpulkan bahwa motivasi narapidana untuk mengikuti kegiatan pembinaan kemandirian tersebut berdampak positif, dari sudut pandang sebagai sekedar pengisi waktu kemudian berkembang menjadikan keterampilan sebagai usaha sumber pendapat dibidang ekonomi .

\section{Kendala Dalam Pelaksanaan Program Pembinaan Kemandirian}

1. Tidak semua narapidana yang berminat mengikuti program kegiatan kemandirian dapat langsung ditampung.

2. Tidak semua program kegiatan kemandirian bidang kerja mendapatkan upah kerja.

3. Terdapat kekosongan pejabat bidang kegiatan kerja yaitu Kasi Kegiatan kerja, dan Kasubsi sarana Kerja.

4. Terbatasnya dana, sarana dan prasara kegiatan kerja.

5. Kurangnya kerjasama dengan pihak ketiga di bidang program kemandirian. 


\section{Kesimpulan}

Kesimpulan yang dapat diambil motivasi narapidana perempuan di Lembaga pemasyarakatan perempuan Kelas IIA Bandung dalam mengikuti program pembinaan kemandirian adalah sebagai berikut :

1. Narapidana yang mengikuti kegiatan kerja adalah ingin mengisi waktu luang.

2. Narapidana berkeinginan mendapatkan uang sebagai upah hasil kerja.

3. Ingin mendapatkan keterampilan sesuai dengan minat dan bakatnya sebagai bekal setelah bebas.

4. Ingin mengembangkan ketrampilan setelah bebas dan dapat menciptakan usaha sebagai mata pencaharian.

\section{Implikasi}

Berdasarkan hasil penelitian maka dapat dikemukakan implikasi sebagai berikut :

1. Lapas kelas perempuan kelas IIA Bandung hendaknya dapat menampung narapidana di program kegiatan kemandirian sesuai dengan minat dan bakatnya.

2. Lapas perempuan kelas IIA Bandung harus mampu memenuhi sumber daya manusia di bidang kegiatan kerja baik secara kualitas maupun secara kuantitas.

3. Segera mengisi jabatan yang kosong pada bidang kegiatan kerja.

4. Menyediakan dana, sarana dan parasaran yang dibutuhkan di bidang program kegiatan kerja.

5. Meningkatkan kerjasama (MOU) dengan Instansi terkait, LSM dan berbagai pihak sehingga dapat memberikan kontribusi bagi PNBP di bidang program pembinaan kemandirian.

\section{Referensi}

Bahrudin Surjobroto, (2002) "Bunga

Rampai Pemasyarakatan, kumpulan

tulisan almarhum mantan kepala direktorat pemasyarakatan diterbitkan dalam rangka hari bhakti pemasyarakatan ke-38", untuk kalangan sendiri.

Buchari Zainun Dr, (1984) "Manajemen dan Motivasi" , Balai Aksara .

Samsudin, Sadili. (2006). "Manajemen Sumber Daya Manusia”, CV Pustaka Setia. Bandung

Malthis. 2006. Manajemen Sumber Daya Manusia. Salemba Empat. Jakarta

Didin Sudirman. (2007). "Reposisi dan Revitalisasi Pemasyarakatan dalam system peradilan pidana di Indonesia". Pusat Pengkajian dan pengembangan kebijakan Departemen Hukum dan HAM RI.

Kementerian Kehakiman Republik Indonesia. (1990). Keputusan Menteri Kehakiman Republik Indonesia No: M.01-PK.04.10 Tahun 1990 tentang Pola Pembinaan Narapidana/Tahanan. Jakarta.

Kementerian Koperasi dan Pembinaan Pengusaha Kecil. (1995).Keputusan Menteri Koperasi dan Pembinaan Pengusaha Kecil. Nomor. 961/KEP/M/XI/1995. Surabaya.

Presiden Republik Indonesia. (1999). Peraturan Pemerintah Republik Indonesia No.31 Tahun 1999 tentang Pembinaan dan Pembimbingan Warga Binaan Pemasyarakatan. Jakarta.

Republik Indonesia. (1995). UndangUndang Republik Indonesia No.12 Tahun 1995 tentang Pemasyarakatan. Jakarta.

Octavia Tria Abati. (2007). Skripsi :"Pola Pembinaan Narapidana Untuk Melatih Kemandirian Berwirausaha Di Lembaga Pemasyarakatan Klas 
Ilb Klaten" . Jurusan Bimbingan dan

Konseling Islam Fakultas

Ushuluddin Negeri Surakarta.

Kiki Cahaya Setiawan,(2015)."Pengaruh

Motivasi Kerja Terhadap Kinerja

Karyawan Level Pelaksana Di Divisi

Operasi Pt. Pusri Palembang".Jurnal

Psikologi Islami.

Erina Suhestia Ningtyas, Abd. Yuli Andi

Gani, Sukanto.(2013). “Pelaksanaan

program pembinaan narapidana

pada lembaga pemasyarakatan

dalam rangka pengembangan

sumber daya manusia (studi pada

lembaga pemasyarakatan klas IA

Lowokwaru Kota Malang)".Jurnal

Administrasi Publik.

Aldo Herlambang Gardjito Mochammad

Al Musadieq Gunawan Eko

Nurtjahjono. (2014). "Pengaruh

Motivasi Kerja Dan Lingkungan

Kerja Terhadap Kinerja Karyawan

(Studi pada Karyawan Bagian

Produksi PT. Karmand Mitra

Andalan Surabaya)". Jurnal

Administrasi Bisnis.

Yoeyong Rahsel.(2016)."Pengaruh

Motivasi Kerja Terhadap Kinerja

Pegawai Administrasi Pusat

Universitas Padjadjaran Bandung

(Studi Pada Bagian Administrasi Umum Unpad)". Jurnal Manajemen Magister, Vol. 02. No.02, Juli 2016

Sumber website

M.Rangga WK-Prima Naomi.artikel :

Pengaruh motivasi diri terhadap kinerja belajar mahasiswa (studi kasus pada mahasiswa universitas paramadina)

http://jurnal.upi.edu/file/M._Rangga _.pdf

Junawan71.blogspot.com.(2017)."Kehidu

pan di Penjara". 